\title{
VÝPOVĚĎ PRO NADBYTEČNOST A KRITÉRIA VÝBĚRU: KOMPARATIVNÍ SROVNÁNÍ
}

\author{
JAKUB TOMŠEJ*
}

\begin{abstract}
Redundancy dismissal and selection criteria: comparative analysis
The article compares the Czech and the British legal regulation with regards to the question, whether an employer, when dismissing an employee due to redundancy, has an obligation to define and disclose criteria, based on which an employee was selected out of a pool of employees performing the same type of work.
\end{abstract}

Keywords: termination of employment; redundancy; selection criteria

Klíčová slova: skončení pracovního poměru; nadbytečnost; kritéria výběru

DOI: $10.14712 / 23366478.2019 .12$

\section{ÚVODEM}

Jedním z hlavních projevů ochranné funkce pracovního práva je, že zaměstnavatel může jednostranně vypovědět pracovní poměr jen z důvodů stanovených v zákoníku práce. Důvody, pro které tak může učinit, se v čase téměř nemění a odráží historickou zkušenost $\mathrm{s}$ tím, $\mathrm{v}$ jakých prípadech po zaměstnavateli nelze rozumně požadovat, aby zaměstnance dále zaměstnával.

Realita života je vždy pestřejší než litera zákona a nastávají tak i situace, kdy se zaměstnavatelé chtějí rozloučit se zaměstnanci z jiných než zákonem zmiňovaných důvodů. Zpravidla jde o situace, kdy je zaměstnavatel se zaměstnancem nespokojen, avšak není naplněna skutková podstata žádného výpovědního důvodu nebo hrozí, že by se v prípadě soudního sporu zaměstnavateli nepodařilo unést důkazní břemeno ohledně jejího naplnění. Důvody nespokojenosti zaměstnavatele mohou být $v$ jednotlivých případech i diskriminační nebo jinak zavrženíhodné.

$\mathrm{V}$ podobných př́ipadech zaměstnavatelé zpravidla hledají, jaký jiný výpovědní důvod by mohli použít, nebo alespoň jakým jiným výpovědním důvodem by mohli zaměstnanci hrozit a tím ho přmimět k sjednání dohody o rozvázání pracovního poměru za

\footnotetext{
* Autor je odborným asistentem na katedře pracovního práva a práva sociálního zabezpečení Právnické fakulty Univerzity Karlovy.
} 
pro ně výhodných podmínek. Asi nejjednodušší variantou je v takovém případě výpovědní důvod podle $\S 52$ písm. c) zákoníku práce, tedy nadbytečnost zaměstnance. $\mathrm{Na}$ rozdíl od ostatních důvodů pro ni totiž nemusí být splněna žádná zvláštní podmínka na straně zaměstnance ani tento důvod na straně zaměstnavatele nevyžaduje žádné výrazné změny (nadbytečnost sice musí vyplývat $\mathrm{z}$ organizační změny, ta však může spočívat právě jen ve zrušení pozice zaměstnance, který u zaměstnavatele již není vítán).

Výpovědní důvod související s nadbytečností zaměstnance je zcela legitimní a v praxi nenahraditelná věc a účelem tohoto článku není tvrdit opak. Domnívám se však, že u daného výpovědního důvodu je nutné vnímat i jeho „negativní potenciál“" související právě s možným zneužitím. Vykonává-li danou práci pro zaměstnavatele jen jediný zaměstnanec, lze tohoto negativního potenciálu využít jen do té míry, do jaké míry se zaměstnavatel bez dané práce (alespoň dočasně) obejde. Ztrátě pracovní pozice, kterou zaměstnavatel fakticky nechce zrušit, se praxe někdy snaží předejít tak, že zaměstnavatel rozhodne o zrušení pracovní pozice zaměstnance a následně vytvoří pozici velmi podobnou; podobné př́ípady nicméně často neobstojí v soudním přezkumu. ${ }^{2}$

O poznání jednodušší bývá situace zaměstnavatele tam, kde totožnou práci vykonává více zaměstnanců. $V$ takovém př́padě totiž zpravidla půjde snáze rozdělit práci zaměstnance, jehož pozice byla zrušena, mezi ostatní zaměstnance, a mnohem lépe se „ztrati““ i situace, kdy je např́klad uměle vytvořena jedna pracovní pozice jen proto, aby druhá pozice mohla být o několik měsíců později zrušena s poukazem na vzestup a pokles množství pracovních úkoli̊; judikatura $\mathrm{v}$ takových prípadech obvykle akceptuje právo zaměstnavatele změnit rozhodnutí, které se ukázalo jako nesprávné nebo neúčinné, jsou-li k tomu dány provozní důvody. ${ }^{3}$

V tomto krátkém článku bych rád pojednal o tom, jakým způsobem právo reguluje proces, $v$ němž zaměstnavatel vybírá, koho ze zaměstnanců pracujících na stejné pozici se propuštění pro nadbytečnost dotkne. Vzhledem $\mathrm{k}$ tomu, že české právo tuto oblast př́liš neřeší, pojednám pro srovnání s úpravou Velké Británie, a na závěr bych se rád zamyslel nad tím, do jaké míry by bylo vhodné se touto úpravou inspirovat.

\section{1. ČESKÁ PRÁVNÍ ÚPRAVA}

Z ustanovení § 52 písm. c) zákoníku práce vyplývá, že zaměstnavatel může dát zaměstnanci výpověd', stane-li se zaměstnanec nadbytečným vzhledem k rozhodnutí zaměstnavatele nebo př́slušného orgánu o změně jeho úkolů, technického vybavení, o snížení stavu zaměstnanců za účelem zvýšení efektivnosti práce nebo o jiných organizačních změnách. Právní teorie dovodila, že platná výpověd’ musí splňovat tři předpoklady: musí existovat rozhodnutí o organizační změně, zaměstnanec se musí stát

2 Zajímavým př́kladem z poslední doby, jak soudy $\mathrm{k}$ podobným případům přistupují, je např. rozsudek Nejvyššího soudu ČR ze dne 19. 12. 2017, sp. zn. 21 Cdo 4568/2017.

3 Srov. např. rozhodnutí Nejvyššího soudu ČR ze dne 4. 4. 2012, sp. zn. 21 Cdo 1001/2011. 
nadbytečným a mezi rozhodnutím a nadbytečností zaměstnanci musí být dána příčinná souvislost. ${ }^{4}$

Bližší postup zaměstnavatele v souvislosti s rozhodnutím o organizační změně zákon neupravuje. Ze zákona ani z judikatury nevyplývá, $v$ jaké fázi se zaměstnavatel rozhodne o tom, kterého konkrétního zaměstnance se změna dotkne, tj. zda by zaměstnavatel měl v rozhodnutí již uvést jednotlivé zaměstnance, jež budou změnou dotčeni, nebo zda má zaměstnavatel nejdřive rozhodnout o organizační změně a až následně vybrat její „oběti“. S ohledem na to, že zákon v tomto směru žádné povinnosti neukládá, i na povahu rozhodnutí, které se považuje za faktické, a nikoli právní jednání, je zřejmé, že výběr postupu je na zaměstnavateli a uvedení konkrétního jména zaměstnance v rozhodnutí nutné není. Obdobně zákon nereguluje ani proces výběru nebo jiné povinnosti, které by zaměstnavatel $\mathrm{v}$ tomto ohledu měl.

Pouze v př́padě hromadného propouštění § 62 odst. 2 a 3 zákoníku práce stanoví, že před dáním výpovědí je zaměstnavatel povinen zástupce zaměstnanců a místně př́slušnou krajskou pobočku úřadu práce informovat (kromě jiného) o hlediscích navržených pro výběr zaměstnanců, kteří mají být propuštěni, a to nejpozději 30 dnů předtím, než započne doručování výpovědí. Ve druhé zprávě Úřadu práce, kde zaměstnavatel dle $\S 62$ odst. 5 zák. práce shrnuje výsledky jednání se zástupci zaměstnanců a sumarizuje své rozhodnutí o hromadném propouštění, se již o hlediscích nic uvádět nemusí.

Zdá se, že hlavním účelem zahrnutí daného údaje pod první informační povinnost je zájem zákonodárce na tom, aby se zástupci zaměstnanců (nebo sami dotčení zaměstnanci, pokud nejsou zastoupeni) v procesu projednání záměru hromadného propouštění mohli vyjádřit $\mathrm{i} k$ navrženým kritériím výběru a popřípadě se pokusit zmírnit nepříznivé důsledky na zaměstnance tím, že navrhnou jiná kritéria. Návrhy zástupců zaměstnanců však nejsou pro zaměstnavatele závazné. S ohledem na to, že se jedná pouze o navržená kritéria a zaměstnavatel nemá ani povinnost následně sdělit, zda tato kritéria zůstávají v platnosti, se však nezdá, že by zákon s nedodržením daných kritérií spojoval jakékoli následky.

Pokud jde o kritéria výběru, Nejvyšší soud již v devadesátých letech dospěl k závěru, že zákon zaměstnavatelům umožňuje regulovat počet zaměstnanců a že o výběru zaměstnance, který je nadbytečným, rozhoduje výlučně zaměstnavatel. ${ }^{5}$ Soudy podle Nejvyššího soudu nejsou oprávněny $\mathrm{v}$ tomto směru rozhodnutí zaměstnavatele přezkoumávat.

K problematice výběru nadbytečného zaměstnance se Nejvyšší soud následně vyjádřil ještě ve dvou rozhodnutích. V prvním př́ípadě 6 se zabýval neplatností výpovědi dané žalobkyni, která vykonávala práci jako docentka na katedře jazyků vysoké školy, její pozice však byla zrušena (a de facto nahrazena pozicí odborného asistenta s odlišnou pracovní náplní, požadavky na kvalifikaci i odměňováním). Žalobkyně mimo jiné namítla i rozpor takového jednání se zásadou zákazu diskriminace, z rozhodnutí Nejvyšší-

4 Srov. DRÁPAL, L. Komentár k § 52. In: BĚLINA, M. - DRÁPAL, L. a kol. Zákoník práce. 2. vydání. Praha: Nakladatelství C. H. Beck, 2015, s. 319.

5 Rozsudek Nejvyššího soudu ze dne 25. 8. 1998, sp. zn. 2 Cdon 1130/97.

6 Rozhodnutí Nejvyššího soudu ČR ze dne 28.02.2012, sp. zn. 21 Cdo 4574/2010. 
ho soudu však nevyplývá, že by žalobkyně tvrdila, že je u ní dán některý diskriminační důvod (např. že $\mathrm{k}$ dání výpovědi došlo $\mathrm{z}$ důvodu jejího pohlaví).

$\mathrm{V}$ druhém př́padě 7 žalobce napadl výpověd' $\mathrm{z}$ důvodu nadbytečnosti proto, že se domníval, že ve skutečnosti nebyla u zaměstnavatele realizována organizační změna, nýbrž se jednalo o akt osobní odvety zaměstnavatele (resp. jeho jednatele) z důvodu „rozdílných názorů otce žalobce na vedení a správu majetku žalované společnosti“, v čemž žalobce spatřoval „diskriminaci z důvodu rozdílného světového názoru“.

Nejvyšší soud v obou daných př́padech zopakoval názor, že je na zaměstnavateli, aby vybral, který zaměstnanec se stane nadbytečným, a v prvním př́ípadu dokonce uvedl, že „protože [...] regulovat počet zaměstnanci̊ a jejich kvalifikační složení je podstatou oprávnění zaměstnavatele upravovat a ř́dit svoji vlastní činnost, nemůže být takové rozhodnutí zaměstnavatele diskriminačním jednáním; nejde ani o jednání označené v ustanovení § 16 zák. práce, prípadě v zákoně č. 198/2009 Sb.“

Výklad výše uvedených rozhodnutí může být komplikovanější. Rovné zacházení se zaměstnanci a zákaz diskriminace platí dle $\S 1$ a odst. 1 písm. e) zák. práce za základní zásadu pracovního práva a současně i za hodnotu, která chrání veřejný pořádek. Ustanovení § 16 zák. práce pak výslovně zakazuje jakoukoli diskriminaci. Rozdílné zacházení se nepovažuje za diskriminaci výjimečně jen tam, kde z povahy pracovních činností vyplývá, že takové rozdílné zacházení je podstatným požadavkem nezbytným pro výkon práce, splňuje-li taková výjimka požadavek na oprávněný účel a přiměřený požadavek (§ 16 odst. 4 zák. práce).

V souladu s tím i Nejvyšší soud v mnoha př́padech akceptoval, že ustanovení o zákazu diskriminace (at' už vyplývají z antidiskriminačního zákona, nebo přímo ze zákoníku práce) dopadají i na právní jednání zaměstnance, jimiž se končí pracovní poměr. ${ }^{8}$ Jestliže v citovaném rozsudku uvedl, že tento zákaz dopadá i na "zjednodušený” způsob skončení pracovního poměru, jakým je zrušení ve zkušební době, pak není jediný důvod, proč by nemělo dopadnout i na výpověd' pro nadbytečnost. Výše uvedené formulaci Nejvyššího soudu (vyslovené v případu, v němž zřejmě nebyly tvrzeny rozhodné skutečnosti týkající se diskriminace) je proto možno rozumět spíše tak, že diskriminačním jednáním nemůže být rozhodnutí o organizační změně (které, jak jsme uvedli výše, není právním jednáním), nýbrž až právě výpověd’.

Navzdory výše uvedenému se tak domnívám, že $\mathrm{v}$ případě, kdy zaměstnanec prokáže, že byl pro nadbytečnost vybrán výlučně z diskriminačních důvodů, je na místě, aby výpověd' byla $\mathrm{v}$ takovém př́padě posouzena jako neplatná. Tento závěr ostatně potvrdil i Ústavní soud, když v jednom případě $\mathrm{k}$ výše uvedenému názoru Nejvyššího soudu vyslovil tuto repliku: „Provádět organizační změny je jistě přirozené a nutné, ovšem tato svoboda zaměstnavatele nutně podléhá korektivu v podobě zákazu rozlišovat osoby, jichž se změny dotknou, podle nepřijatelných kritérii zapovězených Listinou. V tomto smyslu je nutno usměrnit úvahu obecných soudü, že je věcí zaměstnavatele, které zaměstnance v prípadě organizačních změn vybere jako nadbytečné. Naopak, obzvláště ve světle stěžovatelem předložené statistiky bylo žádoucí pozorně zkoumat, zda jako

7 Rozhodnutí Nejvyššího soudu ČR ze dne 15.08.2012, sp. zn. 21 Cdo 2536/2011.

8 Rozhodnutí Nejvyššího soudu ze dne 21. 4. 2009, sp. zn. 21 Cdo 2195/2008.. 
kritérium pro výběr nadbytečných nebyl skrytě zvolen jejich věk (eventuálně snad jiný znak, který byl zákonikem práce vyloučen).“9

Pokud postup zaměstnavatele nelze označit za diskriminační, pak je zřejmé, že se v plném rozsahu uplatní výše popsaný názor Nejvyššího soudu, podle něhož je výběr zaměstnance dotčeného organizační změnou, včetně výběrových kritérií (nebo skutečnosti, že se zaměstnavatel rozhodl zcela nahodile bez výběrových kritérií) na rozhodnutí zaměstnavatele a soud jej nebude přezkoumávat.

\section{BRITSKÁ PRÁVNÍ ÚPRAVA}

Ochranná ustanovení britského pracovního práva jsou zahrnuta zejména v zákoně o právech zaměstnanců (Employment Rights Act - ERA 1996). Ten obsahuje i ustanovení o skončení pracovního poměru. Jedním z důvodů skončení pracovního poměru je i nadbytečnost zaměstnance (článek 139 ERA), která mírí na stejné případy v praxi, jako je tomu v ČR. ${ }^{10}$

Aby skončení pracovního poměru pro nadbytečnost bylo platné, musí být dle britské doktríny splněny dvě podmínky: jednak musí být záměr propuštění se zaměstnancem předem projednán a jednak musí být zvolena správná kritéria výběru. ${ }^{11}$ Kritéria výběru samozřejmě přijdou na řadu jen tehdy, kde by rozhodnutím o nadbytečnosti mohlo být dotčeno více zaměstnanců, avšak zaměstnavatel se chce rozloučit jen s některými $\mathrm{z}$ nich. K věci se váže klíčové soudní rozhodnutí ve věci Williams v Compair Maxam Limited $^{12}$ ( $\mathrm{z}$ doby ještě před přijetím zákona ERA). Z něho vyplývá, že kritéria výběru musí být zaměstnavatelem stanovena objektivně a zahrnovat hlediska jako napríklad docházka, efektivita práce, zkušenost, délka pracovního poměru, a neměla by být založena výlučně na subjektivním názoru hodnotící osoby. Výběr nadbytečného zaměstnance by pak měl proběhnout spravedlivě za zohlednění daných kritéríi.

Právo nestanoví, jaká konkrétní kritéria by měla být používána, a nechává tedy toto rozhodnutí na zaměstnavatelích. V ERA však najdeme ustanovení obsahující mnoho hledisek, k nimž zaměstnavatelé přihlížet nesmějí: kromě jiného jde o skutečnosti spojené s rodinným stavem zaměstnance, aktivitu v oblasti BOZP, podání žádosti o flexibilní pracovní dobu, důvody související s uplatňováním zákonných práv zaměstnanců, členstvím v odborové organizaci a podobně. ${ }^{13}$ Použití diskriminačního kritéria by ve všech př́padech vedlo $\mathrm{k}$ závěru o neplatnosti výpovědi (unfair dismissal). Problémová jsou i nedostatečně objektivní kritéria v zákoně výslovně neuvedená (napřs. „,oddanost““ zaměstnavateli v prŕípadu Everitt v Sealine International Limited $\left.{ }^{14}\right)$.

\footnotetext{
9 Nález Ústavního soudu ze dne 30. 4. 2009, sp. zn. II. ÚS 1609/08

${ }^{10} \mathrm{~K}$ pojmu nadbytečnosti v britském právním řádu srov. též UPEX, R. - HARDY, S. The Law of Termination of Employment. 8. vydání. Bristol: Jordan Publishing, 2012.

11 YEW, J. (ed.). Termination of Employment. Issue 61. Londýn: Bloomsbury Professional, 2018, část C1, S. 50 .

12 Williams v Compair Maxam Ltd [1982] ICR 156. Jde o rozhodnutí Pracovního odvolacího tribunálu (Employment Appeal Tribunal).

13 Srov. zejména ustanovení § 98 - 105 ERA (1996).

14 Everitt v Sealine International Limited, Employment Tribunal, 13134646/09.
} 
Doktrína ${ }^{15}$ tak uvádí, že za objektivní a přípustná kritéria je možno považovat zejména výkon, schopnosti, kvalifikaci, pracovní kázeň, dodržování pracovní doby a přesnost a podobná hlediska.

Aplikace těchto kritérií z praktického pohledu znamená, že v některých případech může dojít $\mathrm{k}$ (skutečnému či zdánlivému) souběhu dvou výpovědních důvodů. Pokud by např́klad byl zaměstnanec propouštěný pro nadbytečnost vybrán na základě toho, že měl největší problémy s dodržováním pracovní doby, mohou být ve hře dva výpovědní důvody: nadbytečnost a porušování pracovních povinností. Nepřekvapí, že britské právo v takovém př́padě za klíčový považuje důvod nadbytečnosti, a v souvislosti s možným porušováním povinností zaměstnance na výpověd' nejsou kladeny nároky, které by zaměstnavatel musel splnit, pokud by výpověd' byla dána $\mathrm{z}$ tohoto důvodu (zejména tedy není nutné, aby intenzita porušení odůvodňovala skončení pracovního poměru z důvodu porušování povinností zaměstnance). ${ }^{16}$

V př́padu Alexander v Brigden Enterprises ${ }^{17}$ Pracovní odvolací tribunál rozhodl, že povinností zaměstnavatele je seznámit zaměstnance s tím, jaká výběrová kritéria zvolil a jak byl zaměstnanec hodnocen.

V praxi je běžné, že detaily postupu upravují vnitřní předpisy zaměstnavatele. Pro názornost je možno odkázat na veřejně dostupnou ,Redundancy Policy“ Birkback University of London, ${ }^{18}$ která stanoví, že v prípadě nezaměstnanosti je povinností zaměstnavatele (v konkrétní rovině vedoucího daného oddělení po dohodě s HR) určit skupinu zaměstnanců, mezi nimiž bude proveden výběr (tzv. selection pool). Současně stanoví kritéria výběru, která budou se zaměstnanci projednána. Vnitřní předpis nestanoví závazná kritéria, uvádí však jejich demonstrativní výčet. ${ }^{19} \mathrm{Na}$ základě těchto kritérií budou zaměstnanci posouzeni; dodejme, že toto posouzení v praxi zpravidla probíhá tak, že zástupci zaměstnavatele jednotlivé zaměstnance bodují a následně se porovnává, který zaměstnanec získal nejméně bodů. ${ }^{20}$ Celý postup a jeho výsledek musí být písemně zdokumentován. Judikatura však samozřejmě respektuje právo zaměstnavatele posoudit splnění jednotlivých kritérií a tento krok je tak zpravidla soudy přezkoumáván nanejvýš jen v omezeném rozsahu. ${ }^{21}$

\section{ZÁVĚREM}

Zákonná ustanovení o skončení pracovního poměru musí rozumně vyvažovat zájem zaměstnavatele na svobodě podnikání, k němuž patř́i i (pro jednotlivé

15 Op. cit. sub. 9, s. 53.

16 Kol. autorů: Redundancy. Employment law handbook. Londýn: Thomson Reuters (Professional) UK, 2016, s. 94 .

17 Alexander and Hatherley v Bridgen Enterprises Ltd: [2006] UKEAT 0107_06_1204.

18 Srov. <http://www.bbk.ac.uk/hr/policies_services/policies_az/redundancypolicy2013>.

19 Zajímavostí je, že v tomto případě jde o vysokou školu a jēním ze zvolených kritérií je i zpětná vazba od studentu.

20 Taková praxe vyplývá z osobních zkušeností autora i mj. z rozhodnutí Watkins v Crouch t/a Temple Bird Solicitors 2011 IRLR 382, o kterém rozhodoval Pracovní odvolací tribunál.

21 Op. cit. sub 14, s. 295. 
zaměstnance mnohdy nepř́ijemná) rozhodnutí o organizačních změnách, a zájem zaměstnance na stabilitě pracovního poměru. Pokud jde o skončení pracovního poměru pro nadbytečnost, klade náš právní ŕád důraz zejména na flexibilitu na straně zaměstnavatele. Ochrana zaměstnance je pak zajištěna zejména prostřednictvím výpovědní doby a odstupného, jimiž je zaměstnanec $\mathrm{v}$ případě skončení pracovního poměru alespoň na nějakou dobu zajištěn.

Byt' možnost zneužití výpovědi pro nadbytečnost není nijak nová22 domnívám se, že české právo nedostatečně chrání zaměstnance před tímto rizikem. Závěr judikatury o tom, že výběr zaměstnance dotčeného nadbytečností je zcela na zaměstnavateli, není v kontextu naší právní úpravy překvapivý, zásadám zvláštní zákonné ochrany postavení zaměstnance a dalším zásadám pracovního práva by však dle mého názoru lépe vyhovoval jiný př́istup. Za překvapivou a složitou pak považuji situaci ve vztahu k možným diskriminačním důvodům, kde judikatura Nejvyššího soudu (byt' částečně korigovaná judikaturou soudu Ústavního) může vést adresáty práva $\mathrm{k}$ (dle mého názoru nesprávnému) závěru, že ani v tomto př́padě nejsou před výpovědí chráněni.

Britská právní úprava skončení pracovního poměru pro nadbytečnost prošla dlouhým vývojem a je velmi složitá. Pro zaměstnavatele z ní vyplývá řada povinností, z nichž ne všechny mohou být přenositelné do našeho právního řádu. Domnívám se nicméně, že tato úprava v hrubých obrysech vede $\mathrm{k}$ spravedlivějšímu nastavení pracovního trhu. Každý racionální zaměstnavatel, který provádí upř́ímně míněnou organizační změnu, totiž beztak musí projít kroky, s nimiž britská úprava pracuje: určit kritéria výběru nadbytečného zaměstnance a za pomoci těchto kritérií rozhodnout. Pokud by tedy i u nás zákon zaměstnavatelům výslovně uložil oba kroky provést, nepožadoval by po nich nic nového ani nadbytečného, a nelze předpokládat ani významné navýšení administrativní zátěže. Výslovná povinnost formulovat výběrová kritéria a řídit se jimi však zaměstnance ochrání v řadě př́padů, kdy zaměstnavatel institut výpovědi pro nadbytečnost chce zneužít nebo zvolit kritéria zavrženíhodná. Domnívám se proto, že základ britské právní úpravy (spočívající právě v povinném vymezení kritérií výběru a jejich dodržení) by mohl být vhodnou inspirací i pro českého zákonodárce.

JUDr. Jakub Tomšej, Ph.D.

Právnická fakulta Univerzity Karlovy

tomsej@prf.cuni.cz

22 Lze odkázat např̀. na práci ŠTEFKO, M. Výpověd’ pro nadbytečnost jako nástroj diskriminace z důvodu věku, Právní rozhledy, 2018, č. 15-16. 